\title{
THE ELEMENTS OF A CHRISTOLOGICAL ANTHROPOLOGY
}

\author{
ROWAN WILLIAMS ${ }^{*}$
}

University of Cambridge

\begin{abstract}
Human beings exist in one of two sorts of solidarity, according to St. Paul-the solidarity of sin or alienation 'in Adam' or the solidarity of life-giving mutuality in Christ. There can be no Christian theology of the human that is not a theology of communion-which converges with the conviction that our creation in the divine image is creation in relationality. The image of God is not a portion or aspect of human existence but a fundamental orientation towards relation. This understanding of the divine image in turn points to the way in which-as the Orthodox theologian Vladimir Lossky stresses-a proper understanding of the nature of personal being depends upon a proper grasp of the divine image, including the fact that it is always an image of the divine 'filiation'- the eternal relation of Word to the Father in the Trinity. Our personal flourishing is a filial dependence that liberates and empowers. And what is 'empowered' is the human vocation to make reconciled sense of the material world of which we are part, articulating and serving its Godward meaning, so that we may see our humanity as essentially a priestly calling within the reconciling priesthood of Christ, in whom all things cohere.
\end{abstract}

KEY WORDS: Filiation, Image, Person, Priestliness, Solidarity

\section{Solidarity}

At the heart of Christian language about salvation is the simple statement that the humanity once defined by Adam's rebellion is now defined by Christ's obedience. Paul's painstaking exploration of this in chapters 5 and 6 of his Letter to the Romans - and, in a slightly different register, in the $15^{\text {th }}$ chapter of I Corinthians - sets out something of how this is to be understood. Our natural kinship with Adam means that we are inheritors of the destructive impulse that turns Adam away from God and leads to isolation and death. The biblical narrative is a record of how God's action steadily shifts humanity towards a different kind of kinship_initially the kinship of God's people united by the fact of the covenant, living under a Law that judges and condemns the imbalance and injustice of Adamic life, and ultimately the freely

* ROWAN WILLIAMS (PhD 1975, Oxford University) was the 35th Master of Magdalene College and is an Honorary Professor of Contemporary Christian Thought in the University of Cambridge. 
bestowed kinship with Jesus which makes us inheritors of Jesus' own relation with God-a relation which death cannot touch. Where Adam seeks to create a human destiny independently of relation with God, Jesus lives out a humanity whose identity and integrity are inseparable from God; he lives in obedience to God, not in the sense that he offers an example of unbroken adherence to a set of commands, but that he lives in unbroken alignment with the will and action of divine life-living uninterruptedly what the Law of the First Covenant points to. Adopted into his relation with God by the action of the Spirit, our human lives are gradually brought into the same 'alignment', so that there is living in us something that death cannot touch. 'As all die in Adam, so all will be made alive in Christ' (1 Corinthians 15:22). [Banner M (2014) The Ethics of Everyday Life: Moral Theology, Social Anthropology, and the Imagination of the Human. Oxford: Oxford University Press; especially chapter 2, has some very important reflections on the centrality of redefined kinship in Christian ethics, and the scepticism that ought to be shown by an informed Christian theology towards any sacralising of literal bonds of blood. See also Williams 2018: 52-4.]

Despite some rather literal-minded challenges from modern theologians-e.g. Maurice Wiles's essay 'Does Christology Rest on a Mistake'—nothing here depends on an unreconstructed belief in an historical Adam or a 'Fall' that could in principle be dated: the logic of Paul's argument is to do with different kinds of solidarity in the present-the solidarity of humanity left to itself and the solidarity created by the divine act that affiliates us with Jesus (Wiles 1976: 122-31). But this immediately gives us one of the most obvious building blocks for thinking further about what a Christological anthropology entails. We cannot in this context speak of humanity without speaking of an unlimited solidarity-that is, of a human community whose character and possibilities are the same across every possible local and contingent frontier. Whether or not we are thinking primarily in terms of a single common ancestor for the human race, the point is that the condition of the human race is ultimately one: there is no difference between what makes for the life and well-being of one individual or one group within humanity and what makes for the life and well-being of another. And this in turn means that what wrecks and limits humanity in any one context wrecks and limits every human context: there are no impervious boundaries in time or space that will allow some portion of humanity to secure itself against the inheritance of death. Indeed, the attempt to do this becomes itself one of the most dramatic illustrations of the seduction of the myth of self-made destiny and so of the sovereignty of death. What rescues us from death cannot be an act that separates us from one another, cannot be an act that seeks any local or limited solution to our shared deprivation; it can only be another kind or level of solidarity. Hence the ultimate simplicity of Paul's worldview: we live in one or 
the other kind of solidarity, the death inherited from Adam or the living Body of Christ. And this latter can by definition never be something that is attained, earned or owned by any individual or group; it must be given, it must be a matter of invitation not entitlement.

Thus, a Christological anthropology begins in recognising that our human kinship in all its forms is shot through with a fundamental disorder, which we can describe as the urge to secure who we are in our own self-referential terms, looking for an identity that is clear and open to us, whose limits we can patrol or control, extend or shrink, and which we can defend against rivals. To secure who we are in the contests of human history and society is something we can and must do to avoid losing what we have; and the loss experienced by another is not connected with any loss to-or ofmyself. Yet this pattern of refusal to recognise another's loss as mine leads, with a grim paradoxicality, to a more and more deeply entrenched isolation and a less and less secure sense of who we are. In contrast, the restored kinship that is created by our affiliation with Jesus secures who we are at two fundamental levels. It gives us an identity in relation to God-a 'name' bestowed by God, the mark of recognition in another's regard, which is both the unique and hidden heart of every particular human identity and also the name that belongs to the glorified Christ (see, for example, Revelation 2:17, $3: 5,12)$; and it incorporates us into an exchange of human relatedness in which each radically diverse member is recognisable to every other as the bearer of the same 'Spirit', the same voice in which prayer is made to God as Abba (Romans 8:9-30, 1 Corinthians 12:1-13, etc.). To put it concisely, the believer receives the identity of Christ, becoming, so to speak, recognisable to God as an adopted child-bearing the designation of Christ and speaking with Christ's voice, and recognisable to others as sharing the same life and thus the same inseparable calling. In place of the flawed and partial kinships we create and defend as children of 'Adam', we live in a mutually nurturing and interdependent environment in which no member's growth and maturation is a threat to any other-but also, therefore, an environment in which the loss, failure and pain of any one member is an injury to all.

As we have noted already, this is something that cannot be understood as a goal to be achieved, something proposed to an individual will as a desirable outcome. Once presented in such terms it becomes immediately a goal among other goals, one of the many things that an individual will may seek for itself. So long as this grammar of 'seeking for itself' remains, the basic structure of Adamic kinship is unchanged. Entry into the kinship of Christ is thus death for the individual will as the putative author of its own well-being. 'If it dies, it bears much fruit' (John 12:24): the sheer acceptance of the utterance that names and invites is the task set before the human subject. In the biblical perspective, the new humanity, the kinship of unlimited mutual gift, is 
inaugurated by an initiative that does not come from a human decision-in Hebrew Scripture, the inauguration of a literal but unconventional kinship in the form of an ethnic group identified as partner to a divine 'treaty' or covenant; in the Christian Scriptures, the creation of a communion without ethnic boundaries. In both cases, it is specific historical events that constitute the new kinship group-the call of Abraham and the exodus from Egypt, the resurrection of Jesus of Nazareth-not any human project or any 'given' state of affairs. A Christologically focused anthropology is thus one that imagines human beings as not only inseparably embedded in systems and protocols of mutual recognition, in the mutual investment of assured identity and lifegiving dependence, but also one that sees the human condition as essentially responsive; to be a guest, to be addressed and invited, becomes something basic to any human agent's self-understanding. And accordingly, damaged and disordered models of humanity are those that mute, deny or distort this receptive dimension in human identity, as well as those that nurture the fantasy of independent, self-generating human identities and radically divergent human goods.

In brief, the central elements of Christological anthropology as we might begin to derive it from the basic texts of Christian faith cluster around these models of receptivity and responsiveness, and the reality of a form of human kinship in which the only ultimate good is a good that is shared. Theology across the centuries has spelled this out further in a number of ways-in connection, for example, with the idea of the divine image in humanity, and with reflections on the nature of our adoptive relation with God, and in terms of what the role of human agency is in the entire created order. In what follows, we shall be looking at these themes at greater length. As they unfold, it becomes possible to shape a distinctive understanding of what we mean by terms like 'person and 'freedom'-commonly regarded as the keywords in any Christian doctrine of the human-and more particularly what these words mean in the context of the era we have come to think of as the 'anthropocene', in which the capacity of human agency to affect the overall ecology of the planet appears to be unprecedented. Yet this cannot be merely or even primarily an exercise in seeking stronger motivation for ethical intervention: in its biblical context, it is irreducibly a matter of both imaging our entire identity afresh and of discovering how we are to grow in alignment with what is actual, with the creating reality of God, and thus a matter of how we expose ourselves in the fullest possible way to that reality in prayer as much as in thought and act. The early Christian theologians who saw moral discernment as educating us in the truthful perception of the natural order, and that perception opening up to the reality of God, were articulating the belief that contemplative openness to the divine act is the thread that connects prayer, perception and action, and that the life of what they called nous, the sheer 
capacity for receptive and transformative understanding, was where the divine image was to be sought. [On the patristic scheme of advance from 'practical' to 'natural' contemplation and thence to theologia, the contemplation of God, see, for example Reconstructing the Theology of Evagrius Ponticus: Beyond Heresy, by A. M. Casiday.] All that we say theologically about our humanity must be framed by this sense of connection, and of the 'simplification' of our bodily and mental life, its drawing into unity and coherence, in a way that allows us to act from the centre of what we are in the divine gift. [Terms related to haplos, 'simple', are increasingly used in Greek spiritual writing for the state of the soul in contemplation, especially after Pseudo-Dionysius in the sixth century; see Dionysius, de caelesti hierarchia I.1, I.2, etc. (PG3.121AB).]

\section{Image}

When early Christian writers identify nous as the divine image or the locus of the divine image in humanity, the natural interpretation seems to be that this is the particular 'area' of the human constitution that is marked out as reflecting divine life. God's image is not to be found in any material correspondence, since God is not a material substance comparable to other material substances; and the life of nous is not confined by material circumstances, limited in its exercise by the physicality of what it encounters and interprets. [For a classical statement that the life of nous is not confined by material circumstances see Origen's de principiis I.1.6 (1913: 20-23).] It is the seat of free selfdetermination, and as such it can be seen as the ground of those actions where the human subject acts in a 'godlike' way. But, as a number of significant studies have shown over more than half a century, this as it stands is a misleading characterisation of what the doctrine asserts. Vladimir Lossky, writing in 1957 and commenting on Henri Crouzel's monograph on Origen's doctrine of the divine image, carefully distinguishes the idea of some aspect of humanity that corresponds to the divine from that of a relationship in virtue of which the divine becomes perceptible (Lossky 1974: 125-39). The former, he says, still carries the traces of a pre-Christian doctrine of suggeneia between God and the finite self-the assumption that they are two instances of one kind of life. Such traces remain visible in the theology of otherwise impeccably orthodox Fathers; but their distinctive teaching centres upon the convention of speaking of the eternal Logos or Son as the Father's eikon, an idiom very common up to the middle of the fourth century, with its origins in the deuterocanonical 'Wisdom of Solomon' (7:25-6) and the language of Paul in Colossians 1:15. The Logos is (Lossky quotes Gregory Nazianzen) the 'definition' (horos) of the Father: the simple reality of the Father (immaterial, unchanging, non-composite) can be shown only in the life of another divine subsistent sharing exactly the same simplicity. God is such that only God can 
represent God truthfully (See Or. 3020 in Gregory Nazianzen 1978: 268, 9). But at the same time, this representation of the Father shows us that the Father does not possess divinity in isolation: the repeatability of the divine life we call 'Father' manifests the relational character of divine life: it can be shown because it is always already shared.

But, as Lossky stresses, this means that the divine image cannot be thought of as the reproduction of a part or aspect of one subject in some part of another. The way in which the Son can be thought of as the Father's image has nothing to do with the enumeration of various respects in which one resembles the other: it is a matter of how the act of the Father is received and reenacted in its wholeness in the life of the Son. And the sense in which human beings can be understood as made in God's image is determined by this prior understanding of the image relationship. 'Christ', says Origen, 'is the first principle [arche] of those who are made according to God's image'; we image Christ in the way that Christ images the Father (Origen 1903: 22). That is, the human nous, the capacity for living in total conscious responsiveness to the gift of God, manifests in the entirety of its action the 'repeatability' of the life of the divine Logos - that is, it manifests the Logos as eternal response to the Father, the Logos in its eternal relation of re-enacting the life of the Father. As Lossky puts it elsewhere, this implies that the image of God in humanity cannot be thought of in 'objective' terms as an aspect of human nature; it is human identity living in alignment with the Logos's own alignment with the ultimate source of divine reality (Lossky 2012: 101; c.f. Lossky 1974: 120). That alignment is embodied, of course, in the incarnate life of the Logos: human responsiveness to the self-gift of God is inescapably a matter of the shape of an embodied life, growing into its maturity in relation with a material world-hence the intrinsic connection between behavioural maturation (the praktike theoria of the Greek ascetical writers), perception of order in the world (physike theoria) and the intimate contemplation of the divine. What is given or restored or brought to full maturity in Christ (and all these terms are defensible in different contexts as descriptions of what Christ does) is the freedom of responding to what is not the self in a 'truthful' way-i.e. without the distortions of our self-protecting and self-isolating agendas. In slightly more abstract terms, it is the capacity for knowledge in communion-awareness of and participation in the agency or energy that surrounds us. To recognise Jesus Christ as the incarnation of the Logos is to affirm, among other things, that his human identity is the place where unqualified intimacy with or openness to the Father makes possible an unqualified liberty to relate transformingly to every finite situation and every finite subject.

To quote Lossky once more, this means that identifying the image of God in humanity is never a matter of looking for 'a certain something' in human nature that can be distinguished from other aspects of humanity that lack the 
divine image (Lossky 1974: 138). If we say, along with the great mass of the theological tradition, that the image is 'in' the nous or, more loosely, the 'soul' rather than the body, this is seriously misleading if what we mean is that one part of human nature is 'more like'; God than another. That would take us back to the impossible notion of God and the soul as two comparable instances of free and spiritual substance. The truth of saying that the image is in the nous is simply to deny that the language of image here has anything to do with external resemblance, and that the core of the doctrine is something about the character of our relation to God and the character of God as generating and inviting response, a response that is at its fullest when the whole of our subjectivity is involved. But Lossky, like other modern Orthodox theologians, goes rather further in following through the implications of this: if the life of the nous in the extended sense we have given the phrase, is where the image of God is identifiable, that image is bound up with the possibility of engagement in, 'investment' in, the other, and a being-engaged or being-invested-in by the other; and this, says Lossky, tells us that the human person is never properly characterised as an individual instance of a general 'nature' (Lossky 2012: 101-2). The image is 'the liberty of the human being in respect of their nature'. It is set over against the realm of necessity, the predictable behaviours that allow us to categorise some substance as an individual of a certain kind. The person is what exceeds the realm of 'nature' in the sense that 'personal' activity is the unpredictable, cumulative and interactive dimension of human engagement - what might be thought of as (in the widest possible sense) the linguistic, relation-building element, the construction of a shared world of reference and shared ideas and models of human selfhood or agency. It is not a transcendent 'portion' of the human constitution; the person is not an extra bit of nature but is how we understand and speak of the way in which exemplars of human nature construct an identity that is thought, spoken and more or less consciously nurtured. [Lossky is clear that it is not a transcendent 'portion' of the human constitution (1974: 120).]

Summing up this approach to the divine image, we can say that (1) the foundational insight is that God's life is 'repeatable', that divine life is communicable and intelligible because always already given; (2) the finite intelligent and creative subject exists as essentially a reflection of this eternal responsiveness; (3) human fulfilment therefore consists in the activation of a capacity for mutual creative involvement or investment and in exposure to the act of the divine in prayer; and (4) this lays the foundations for a model of personal existence that is set over against the realm of necessity and is realised in the 'excess' of human activity beyond the bare instantiation of natural characteristics. The location of the image in the nous is not a sort of territorial restriction but something more like a 'grammatical' point: to speak of the divine image is not to speak of a material object correlating with another 
'object', material or spiritual, but a way of thinking about the relation of a complex finite agent to infinite agency. Just as, for the patristic tradition the soul is not a part of, or present in a part of, the body, so the image is a pervasive aspect of human existence; the term designates that aspect of human existence which is involved in a solidarity that entails a mutual 'entanglement', such that no particular agent or subject can be thought without thinking the network of relations that constitute it as an active reality. [For a clear statement, see the quotations from Maximus the Confessor's Ambigua ad Iohannem in The Oxford Handbook of Maximus the Confessor (Allen, Neil 2015: 374).] And our language of the person is the clearest vehicle for this, once we have decisively separated this from concepts of mere individuality.

\section{Person}

If we can, as so many Eastern Christian thinkers argue, derive the idea of the personal from a Christologically informed doctrine of the divine image, one implication is that the unity we associate with the notion of personal identity is not simply a given internal characterisation of the human subject. I am 'one' in virtue not of a primitive atomistic core of my being but because of a coherence or integrity in my relations with my environment and my creator. I receive a consistent call: the word by which God has called out a response in this particular enfleshed reality is not rescinded, it does not return empty to God (Isaiah 55:11) but continues to establish an invitation, a space for this enfleshed reality to occupy in God's presence, and indeed in God's life. What the spiritual writers of the tradition describe as the haplosis, the 'simplification', of our human condition in the life of grace is a fixed inhabiting of that divine word of invitation, not seeking to ground our identity anywhere but in that, not in our achievement or standing or in any feature of our natural life, but solely as the recipient of the word. It is a theme that has been developed in Protestant as well as Orthodox theology. Jens Zimmermann, in a valuable recent study of Bonhoeffer, notes the way in which Bonhoeffer maps the tension between the divided self of fallen human subjectivity and the unified reality of life in the divine image: fallen Adam tries to attain, even to seize (Philippians 2:6), equality with God, to become sicut Deus, 'like God', while the image of God is realised precisely when our being in Christ pulls together the divisions of our selfhood into a single act of all-encompassing faith, liberated from the craving for self-justification (Zimmermann 2019: 131). 'This means that from now on I can only find unity with myself by surrendering my ego to God and others' (Zimmermann 2019: 134). To be at one as a person is to 'inhabit' the invitation of God, seeing this as the sole foundation for a security that does not depend on what I can do, what I can master, what I can achieve. 
'Participation in Christ ensures that Bonhoeffer's Christian humanist self is not beset by this rift between desired meaning and a silent universe, or an infinite ethical demand and an absent ethical norm' (Zimmermann 2019: 143). The human person is alive in and only in the reality of Christ's incarnation, in which the fictitious self-sufficient subject is put to death and the ground of action becomes the sheer act of opening up to the purpose and action of the divine Source-yet without becoming impersonal or overriding finite will by the imposition of infinite. Christ is the model of personhood because in him the embodied history of a human agent, developing in time, reacting to contingent situations and so on, is completely 'embedded' or grounded in the eternal responsiveness of the Word of God to the Father's self-giving. When we come to share in the life of Christ, we too are embedded in and come to inhabit that unconditional response; the language and culture we create as finite agents working with and answering to each other, developing the criteria and conventions of human recognisability, are, in Christ, the realisation of the solidarity for which we were made and which we have lost through the partiality and self-interest of the solidarities we create to defend ourselves. What some have called the foundational error of 'self-creation' gives way to the acceptance of our createdness, in a remote but real analogy to the eternal Word's acceptance of derivation form and dependence upon the Father. Thus, as Zimmerman says, there is now no pathos of frustration in a meaningless universe to be negotiated, and no drama of self-transcendence by strenuous ethical self-assertion. Bonhoeffer's Lutheran orthodoxy points him towards the rootedness of all good action in the indwelling of Christ, not in the effort to earn grace and mercy. But-although Zimmerman suggests that Bonhoeffer is deliberately modifying the theology of the patristic consensus - this is entirely congruent with the Greek patristic notion of spiritual maturity as aligning the created logos with the uncreated and leaving behind the 'heavy burden' of self-justification. As Bonhoeffer movingly spells out in his prison poem 'Who Am I?', the 'true' self is what God alone sees-neither the individual self-image nor the performance put on for the sake of a human audience, but the bare location of a divine address and welcome. [The phrase 'heavy burden' of self-justification is ascribed to Abba John the Dwarf (Ward 1975: 77).]

The person realises the divine image precisely by abandoning the aspiration to be like God. Just as, in Philippians 2, Christ fully restores what we have lost by not attempting to be 'godlike' in his earthly life, by renouncing power and advantage, so for the believer affiliated with Christ the image emerges in and only in the embrace of contingency, bodiliness, the lack of any certainty about control of the environment, the processes of growth.

'Person' is in some ways a paradoxical concept. In the light of what we have just been considering, it is crucial that we do not think of person as an 
item within us that we can observe, a 'true self' underlying the artificialities of social and relational identity which needs 'liberating' from these accidents; this is one of the most pervasive and problematic of modern myths. Yet at the same time, the personal is what discloses and is disclosed in relation. The Greek theologian Christos Yannaras, in his seminal work on Person and Eros, writes of logos as the principle of disclosure: the logos that defines personal being is the act of self-unveiling or self-exposing that occurs in relation; each person/logos is unique because each position in the network of relating is unique. Every intelligible reality is 'logical' in the sense that it can be understood and expressed only in relation; but what we all personal being is distinct to the extent that it freely, actively and reflectively shows and communicates what it is. Logos is 'a person's power to reveal and express the uniqueness and dissimilarity of its ecstatic reference and its universal relation with other beings or other persons' (Yannaras 2007: 167). Personal life is 'ecstatic' in the sense that it exceeds the mere activation of a set of generic potentialitiesdoing the sort of thing that this sort of agent does; it is the kind of activity that creates new possibilities of communication because it sets in motion a history, a reflective telling of the world's process that is not just a description of kinds of action and kinds of agent. Personal being is, we have suggested, 'linguistic' being in an extended sense: but so far form this leaving us with a world of atomistic subjects expressing their selfhood, it points to a world in which each point of intersection in the complex of agencies in that world grows into a perceived, located, embodied distinctiveness through declaring itself to and in relation with what it is not. The person is indeed not an item within 'nature' nor a given and deeply buried stratum of sheer naked individuality: but it is that which shapes itself through exposing or declaring itself in relation. The mysteriousness or hiddenness of personal distinctiveness is not the adventitious hiddenness of something which as it happens we cannot see; it is systematically unseeable because it is always coming into being through encounter and reworking or redefining its being in those moments of encounter, of giving and receiving.

When we speak theologically of the 'person' of Christ, we do not refer to some element within a mixture, or to the strange bundle of psychological phenomena we call 'personality'. The classical doctrinal definition of Christ's identity as one person in two natures is meant to clarify the conviction that the mode of response to divine gift that is eternally real in the life of God, showing what God is and reflecting back what God is, is one and the same in the eternal life of the Word and in the human life of Jesus of Nazareth. No analysis of the human nature of Jesus, the bare material individuality of this member of the human race, will uncover some buried element of divinity; the statement that this human individual is the Word of God in flesh means that this human identity as it unfolds or declares and defines itself in history, as it 
speaks and is recognised and responded to, is the point at which God declares and defines God's identity and does so not by delivering a message or a system but by creating a form of solidarity, the Body of Christ, in which human beings are free to declare themselves fully in a reconciled pattern of belonging together that has no natural foreordained limits. A Christologically shaped anthropology is thus one that foregrounds the mystery of the "personal', not as a mystique of fathomless and arbitrary liberty or a sentimentalism about the oddities of human psychology, but as a recognition of the centrality of freely responsive action in any account of the human-action that, in responding to the call or invitation of its divine source, acquires an identity that can be declared or exposed in relation to other created beings.

\section{Filiation}

The eternal Word's relation to the divine source is consistently understood as 'filiation', being a son/daughter; and the sense of this is laid out in human terms in the history of Christ's humanity. If we want to know what the divine relation of begetting and being begotten, Father and Son, looks like in terms that we can to some extent imagine, we have to reflect on this history. It is variously expressed in the gospel accounts, most fully in John's Gospel. The Son receives all that the Father has and knows the Father uniquely (Matthew 11:27); the Father declares himself to the Son, who does what the Father does, sees what the Father is, and reciprocates the self-giving and self-declaring of the Father (John 5:19-27, 17, passim). In other words, what we see as giving consistency or unity to the life of Jesus is the abiding fact of seeing, knowing and reflecting the act that characterises the Father. Jesus gives life as does the Father, realising this in acts of absolution and healing; Jesus shows his followers who the Father is and what the Father does in his own intimate declaration of himself to them-and ultimately in his death understood as an offering that connects them with the Father once and for all. His life is unintelligible, formless, without his unbroken conscious dependence on the Father; he 'can do nothing on his own' (John 5:19), but that dependence makes it possible for him to act authoritatively and freely in the Father's name. He has 'authority to execute judgement' (John 5:27)-i.e. he has the right to determine or define the relation of things and persons in the world to what is truly and ultimately the case, he establishes and enacts the 'truth' which displays what in any situation is in accord with reality and what is fictive and selfserving (e.g. John 5:31-47, 12:46-50, 15:26-16:11). Jesus' dependence on the Father is a matter of consistent attention to the pattern of divine act such that the pattern of his own action takes the same form and consequently has the same authority and the same declaratory and illuminating effect. To live humanly as the divine Son is to be a conduit of divine act, to live in uninterrupted continuity with what God is doing in healing and in judgement. 
A Christological anthropology is thus a model of humanity which sees the acknowledgment of dependence as fundamental. Living as we now do in a cultural context where dependence is so often seen as problematic, this is not a simple notion to clarify (though the notable essay by James Mumford on Ethics at the Beginning of Life includes some very fruitful discussion of the point; note Mumford's emphasis on the idea of kinship as something always prior to any kind of consciously determined 'contract' (2013: 79-118)). However, the narrative and rhetorical shape of the gospels make it plain that the recognition of dependence-and the way in which (to echo Mumford) dependence is understood as one of the things that makes humans recognisable to each other-is the opposite of a recommendation to passivity or a sanctioning of human systems of unquestioned authority. Openness to the sustaining and pervading reality of divine action, both in prayer and in the attentive and interdependent habits of life in the 'kinship' of Jesus, the Body of Christ, means being established at a critical distance from contingent human power, and also being liberated from the sense of having to succeed in imposing one's own agency at the expense of others. If we think back to Bonhoeffer's concern to overcome the divided self of fallen Adam, obsessed by the unattainable goal of being 'like God', we can see that growth towards Christlike dependence is again a way of securing a unity of personal being that does not depend on either a fixed interior identity or a record of satisfactory achievement. Our being in Christ connects us with the unifying and reconciling purpose of God; the more we are identified in and with this purpose, the more our action in the world is in accord with the truth of the world's need and the world's possibilities. 'Dependence' here is a liberation from private fantasy and egotistic struggle and signifies not a reduction or weakening of the reality of finite being in its distinctive embodiments but an establishing of this on the only firm ontological ground it can have, which is the divine invitation (Zimmermann 2019: 188-93). As we noted earlier, the process described in terms of 'simplification' in the spiritual tradition is a process of freeing our finite agency from the distracting and fragmenting compulsions, cravings and fictions that paralyse it. When we are able to live out of the reality of divine invitation, we are at one with ourselves and our neighbours and God; we discover personal integrity in our interdependence within the community of belief, and it is centred in and founded upon our freedom to attend to and receive in prayer the action of God towards us. The prayer, 'Abba, Father', mentioned by Paul in Romans 8 and Galatians 4 as the quintessential utterance of the Spirit within us, is the key to understanding where we derive the mode of agency by which the world might be changed - which is why a properly Christological anthropology illuminates the non-contradiction or non-duality between contemplation and action. 
What humans have to learn in the newly illuminated world of Christocentric reality is the patience to live in the presence of God's invitation and in the utterance of the prayer $A b b a$ as they receive the 'inheritance' promised by their new kinship with Jesus, the incarnate Word, their metaphorical 'descent' from him which heals the damage done to Adam's lineage. The reality of filiation is what is articulated both in silent attention to God and in response to an untransformed and imprisoned world. Contemplation and liturgy are inseparable from the imperatives of active love. And this active love will seek-as one very unusual twentieth century Russian saint, Maria Skobtsova, argued-to bring others into the state of filiation, to allow them to be liberatingly dependent on God's word (2003: 70-5). Anthropological vision entails the commitment to recognise and help actualise in others the same realities out of which we ourselves act, so that these categories of solidarity, the divine image, personhood, and filial liberty give us not only ways of understanding who and what we are in Christ, but a set of aspirations for the humanity we seek to make real around us. The maxim that 'the Holy Trinity is our social programme'-a phrase originating from the nineteenth century Russian philosopher, Nikolai Fyodorov, but discussed in recent years by contemporary theologians like Miroslav Volf — can readily be misunderstood as a naive picture of divine and human 'sociality' assimilated to one another, the persons of the Trinity being thought of as separate subjects brought into harmony; but there is a sense in which it can perhaps be defended. The selfcommunicating, self-repeating life of God is such that its activity sets up a chain of implication for us, whereby we see that what we desire for our own healing is inseparable from the desire for the healing of others-because the communication of who and what God is entails the sharing of an energy that cannot but make for personal communion, and thus cannot but make for a state of affairs in which each agent is involved in bringing alive in every other the reality of self-communicating/self-repeating life-life that gives life and so gives the liberty to give life all over again.

\section{Priestliness}

The calling both to receive and to give life is very particularly crystallised in the liturgical action that declares the Church's identity. In the eucharistic mystery, the community of Christ-centred solidarity 'declares itself' in the act of taking the material stuff of the world and naming it afresh as the vehicle of God's gift. It repeats and inhabits Christ's word and action at the Last Supper in identifying his mortal and suffering body with the shared matter of a meal. It locates itself within the act that is evoked in the Letter to the Hebrews, the passing of Jesus, like the Jewish High Priest, into the Holy of Holies, offering as sacrifice his material humanity-and implicitly the material world that makes this humanity possible, as well as the whole human kindred 
with which the human individual Jesus is in solidarity (Hebrews 4:14-5:10, 7:26-8.7, 9:11-1, etc.). The community affiliated with Christ is described as priestly (1 Peter 2:4-5; and cf. Revelation 22:3-4) primarily because it is taken up into the movement of Christ into the heart of divine holiness through his self-offering, included in his act of uniting earth with heaven. And so the sense that can be made of the world's raw material through the culture of food preparation and food sharing is identified with the sense that is made of the whole human environment by the self-offering of Jesus to achieve reconciliation and absolution for the world.

It is undeniably an intricate set of ideas, and in the history of theology different themes within this complex have emerged at different times; but there is a focal cluster of meanings that has remained fairly consistent, a cluster of ideas that has to do with the transformation of the material order as a dimension of what we are called to affirm and realise in worship. In this context, Christian anthropology has explored the notion of the innate "priestliness' of human existence, at least from the time of Maximus the Confessor in the seventh century. For Maximus, the distinctive role of the human is to be the mediating and uniting agent within creation in virtue of humanity's union with Christ, in whom the divisions and oppositions that characterise creation as we know it are decisively overcome (Maximus, Ambigua ad Iohannem. 41 and cf. Mystagogia 5 and 7). And adapting Maximus's vision to the argument we have so far been exploring, we can see the human renaming of the elements of the world utilised in the eucharist as a refusal to treat the material world as 'dead matter': the human being who is united with the eternal Logos becomes fully logikos, speaks and acts in accordance with the harmonics of the world as God has made it, and so is able to declare or disclose the logoi of the material environment-which means seeing them as vehicles of communion, a world with a common good in which no part can be injured or diminished without hurt to all. The communion of persons in the Body of Christ is, so to speak, extended into a communion with the whole material order, as that order is made to speak of reconciling gift. Nature, we could say, is decisively included in culture, material things become communicative signs without losing their ordinary physicality and distinctiveness.

So, the logic of a Christological anthropology is that humanity's self-disclosure must be a disclosing of the 'logic' of the world around-that is, of the world's relation to the self-giving act of God. We have seen the impossibility of thinking of an individual human identity abstracted from the relations that nurture and make possible disclosure; and the same can now be said about the identity of humanity in collective terms. There is no 'true' human identity that is not always already implicated in the material order, living in and from and with it. And this living in, from and with the rest of the material world involves also the exercise of the unique level of communicative freedom that 
is proper to humans: it involves 'speaking' the material world in harmony, naming it as communicating gift to us. This challenges at the very root the idea that we are free to exercise power over the material world as if it were not already the carrier of grace-existing in relation to God before it exists in relation to us humans. And our capacity to disclose this pre-existing truth and bring it to speech and meaningful action, to bring it to 'culture', is the exercise of our priestly calling. We are most distinctively human when we refuse to think of ourselves in isolation from matter and animality; and thinking of ourselves in solidarity with matter and animality involves, among other things, the thinking of the world around as shot through with the same life of logos that we live from. As Yannaras stresses, the etymological roots of logos have to do with 'collecting' or 'assembling', linking together: recognising that we live in a world united in logos is to recognise our implication in that world and our answerabilty to it (Yannaras 2007: 159-61). If the unity of each human subject is, as we have seen, grounded in the consistency of a divine invitation to participate in the interaction that constitutes the world, we need to think of other substances or agencies in the world in similar terms: they are what they are, they have intelligibility and unity, they can be spoken of and understood, ultimately because of the word that has invited them into life. The life they live cannot be at the mercy of human desire, collective or individual; and we live out our own invited nature, our role in the complex whole, by attending to what God invites other substances to be, and by acting towards them in the light of that discernment. We cannot legitimately ignore this dimension and imagine that all things in the world are there to serve the functions we prescribe for them. It is certainly not an implication of this that we should be passive in the face of our environment (which would in any event be impossible); but the interventions we make, the uses to which we put the stuff of the world, need to be undertaken with a view to the need of the whole and the continuing balance of forces and agencies that keep the system functional and life-giving - the balance that makes it a genuine ecology. As I have argued elsewhere, this is the essence of learning to see the world as 'sacred', in the sense of being radically other to our designs and supposed needs. (Williams 2012: 13-14, 17).

Liturgy, then, is an inescapable dimension of human activity. The culture we create as conscious persons aware of our invitation to live out the filial calling of Christ must be at its most developed and self-aware a liturgical culture-one that celebrates and enacts the transition from slavery to liberty or darkness to light. Christian liturgy presents the narrative of Jesus living out his identity as Logos incarnate by refusing violence and retaliation, renewing his call into 'kinship' in the face of the most extreme rejection and betrayal, and (to return to a point noted at the beginning of this essay) establishing a bond between God and humanity that death cannot cancel. It is the record 
of a life, death and resurrection in which the Adamic urge to isolation, unilateral control and fictive godlikeness is exposed as lethal to humanity and replaced by the gift of a new pattern of relation. Its liturgical enactment declares at the same time the liberating of our intimacy with God, the creation of reconciled and unboundaried solidarity among human beings and the transformation of our perception of the world in the light of this decisive event of peacemaking. Liturgy discloses who we now are as human agents living in Christ, and so discloses-and reinforces-our witness to the unity of creation in the Logos. It ritualises the new state of affairs, but in so doing opens us again to the divine activity that renews us; to act out and 'speak out' the pattern of the new world is in itself to accept and intensify our 'logical' receptivity to God's gift, not only to renew an idea. Liturgy is, in plain words, a moment of grace.

\section{Conclusion}

We began with the Pauline dichotomy between two sorts of solidarity: the negative solidarity which means that we are all involved in limiting or undermining common human life, and the authentic solidarity of what God brings into being initially in the Covenant with the Jewish people and then in the universalised 'kinship system' that is the Body of Christ, the baptised community. Thinking through this transition has brought to light a closely intertwined set of insights about how we understand human possibility and human responsibility. The renewal and universalising of our solidarity depends on the fact that Jesus' humanity is an embodiment of the divine self-communication or self-repetition; and a humanity recreated in the likeness of Jesus will thus be one that 'images' God as Jesus does, allowing itself to become a site for divine self-disclosure and divine response to divine gift. For the image to be fully at work, we need a doctrine of the human person rooted in the trinitarian mystery-not in a way that makes divine personhood an exalted version of finite co-operation but understanding what it means to say that there is literally no individual subject prior to relation and interaction; which means in finite terms, that there is no individual subject prior to history and culture. We are irreducibly historical and so also 'linguistic'; we exist in the medium of communication. Our mysteriousness to one another-a crucial element in our reverence for one another and our proper scepticism about the possibilities of total control over others-is not the inaccessibility of some deeply interior level of our being but the self-renewing and unpredictable working of mutual communication, constantly creating unprecedented situations and so unprecedented combinations of sound and symbol. But the most basic communication remains what God communicates to each active point of convergence in the human world, each historical subject-which is the invitation to intimacy and trust, the grateful acknowledging of 
dependence, and the exercise of a 'divine' freedom for reconciliation and recreation. The divine image is realised in personal agency; and the full and free shape of that personal agency is the filial identity defined by the life, death and rising of the incarnate Logos. And the actualising of this filial life involves a re-presentation of the transforming history at its origins and an effectual sign of human responsibility to create a unified and just meaning for the material world, a culture of reciprocal gratitude, receptivity, and stability.

The often-cited phrase from Irenaeus, 'The glory of God is a human being fully alive', is a deeply Christological formulation-not simply a celebration of humanity in itself. God's glory, God's presence diffusing itself in beauty and illumination, is the presence in the material world of the active reality that mirrors its source in God: the glory of the God who makes covenant and accepts sacrifice (Exodus 24:17-18, 33:1-23, 34:29-35, 1 Kings 8:10-11, etc.), and who declares the divine identity in the face of Jesus and in Jesus' fellowship with the disciples (John 17:22, 2 Corinthians 3:7-4:6). Ultimately a Christological anthropology is one that looks towards the glorifying of humanity though its alignment with the self-sharing and self-showing of God in the eternal Word and the Word made flesh. To be human is to be the site of glory; reflecting God's illuminating beauty in a communion without condition or limit.

\section{Bibliography}

Allen P and Neil Bronwen (eds) The Oxford Handbook of Maximus the Confessor. Oxford: Oxford University Press.

Casiday AM (2013) Reconstructing the Theology of Evagrius Ponticus: Beyond Heresy. Cambridge: Cambridge University Press.

Gregory Nazianzen (1978) Discours 27-34. In Gallay P and Jourjon M (eds) Sources Chretiennes 250. Paris: Cerf.

Lossky V (1974) In the Image and Likness of God. Crewstwood: St. Vladimir's Seminary Press.

Lossky V (2012) Theologie Dogmatique, edited by Clement O and Stavrou M. Paris: Cerf.

Maximus the Confessor. Ambigua ad Iohannem.

Maximus the Confessor. Mystagogia.

Mumford J (2013) Ethics as the Beginning of Life: A Phenomenological Critique. Oxford: Oxford University Press.

Origen (1903) Commentary on John I.XVI, edited by Preuschen E. Leipzig: JC Hinrich.

Origen (1913) De Principiis, edited by Koetschau P. Leipzig: JC Hinich. 
Skobtsova M (2003) Mother Maria Skobtsova: Essential Writings, trans. by Pevear R and Volokhonsy L. Maryknoll, NY: Orbis.

Ward (1975) The Sayings of the Desert Fathers: The Alphabetical Collection. London: Mowbray.

Wiles M (1976) Working Papers in Doctrine. London: SCM Press.

Williams R (2012) Faith in the Public Square. London: Bloomsbury.

Williams R (2018) Christ the Heart of Creation. London: Bloomsbury.

Yannaras C (2007) Person and Eros, Russel N (trans). Brookline, NY: Holy Cross Orthodox Press.

Zimmermann J (2019) Dietrich Bonhoeffer's Christian Humanism. Oxford: Oxford University Press. 